\title{
Państwa skandynawskie wobec zagrożeń społecznych i politycznych związanych $\mathrm{z}$ imigracją
}

\section{Scandinavian countries in the face of social threats and political issues related to immigration}

\begin{abstract}
Streszczenie:
W wyniku zachodzących przemian na świecie w XXI wieku poważnym wyzwaniem jest migracja. Artykuł ma na celu ukazać główne zagrożenia wynikające z imigracji. Analiza powstałych zagrożeń dla bezpieczeństwa społecznego i politycznego państwa w wyniku imigracji pozwoli na określenie możliwych działań. Doświadczenia państw skandynawskich pozwolą na ukazanie możliwych działań minimalizujących zagrożenia. Artykuł opisuje zarys problemu, ze względu na złożoność i obszerność tematu.
\end{abstract}

Słowa kluczowe: bezpieczeństwo społeczne, bezpieczeństwo polityczne, migracja

\begin{abstract}
:
Migration is a serious challenge as a result of global changes in the 21st century. The article aims to show the main threats resulting from immigration. Analysis of the emerging threats to the social and political security of the state as a result of immigration will allow to identify possible actions. The experience of the Scandinavian countries`experience allows us to show possible actions to minimize threats. The article describes the outline of the problem, due to the complexity and broadness of the topic.
\end{abstract}

Keywords: social security, political security, migration 
Marcin Wysocki - Państwa skandynawskie wobec zagrożeń...

\section{Wprowadzenie}

Autor na podstawie wybranych doświadczeń państw skandynawskich, analizuje powstałe $\mathrm{w}$ wyniku imigracji zagrożenia dla bezpieczeństwa społecznego i politycznego. Dania, Szwecja i Norwegia należą do grona krajów zamożnych ${ }^{1}$, przez co państwa te wydają się atrakcyjne dla imigrantów. Natomiast starzejącym się społeczeństwom skandynawskim potrzebny jest napływ młodych ludzi na rynek pracy. Wymienione państwa już od końca II wojny światowej borykają się ze zjawiskiem migracji, a $\mathrm{w}$ dalszej mierze integracji. Doświadczenia państw skandynawskich mogą pomóc w stworzeniu strategii bezpieczeństwa narodowego, która umożliwi podjęcie wyzwań, minimalizację zagrożeń i wykorzystaniu szans jakie przyniesie ewentualny wzrost imigracji do Polski z krajów objętych konfliktami i z niższym poziomem jakości życia. Autor zwraca szczególną uwagę na wyzwania i zagrażanie, ponieważ przyjmuje, że „[...] w badaniach bezpieczeństwa, $\mathrm{w}$ różnym wymiarze, należy wyraźnie eksponować wyzwania i zagrożenia, albowiem tylko takie podejście może doprowadzić do obiektywnej oceny zjawiska bezpieczeństwa"2.

Państwa skandynawskie posiadają wszelkie cechy, aby przyciągać imigrantów. Jest to region stabilny gospodarczo, oferujący cudzoziemcom lepszą jakość życia, a przy tym bardzo tolerancyjny ze swobodami obywatelskimi i religijnymi ${ }^{3}$. Jednak szybko zwiększająca się liczba imigrantów obcych kulturowo i częściowo nie chcących się integrować zwiększa poczucie zagrożenia wśród ludności rdzennej. Dodatkową niechęć do przybyszów zwiększają nagłaśniane przypadki islamskiego terroryzmu, problemy na rynku pracy, występujące kryzysy gospodarcze oraz działania organizacji antyemigracyjnych. Środowiska imigrantów wymagają szczególnej uwagi władz centralnych ze

\footnotetext{
${ }^{1}$ G. Esping-Andersen, Trzy światy kapitalistycznego państwa dobrobytu, Warszawa 2010 , s. 44-47.

2 W. Pokruszyński, Teoretyczne aspekty bezpieczeństwa, Józefów 2010, s. 8.

${ }^{3}$ A. Kobierecka, M. Kobierecki, W poszukiwaniu źródeł międzynarodowej atrakcyjności Szwecji, Wymiar kulturowy, „Politeja” 2017, nr 3 (48), s. 246-247.
} 
względu na problemy integracyjne. Wiąże się to z kosztami ponoszonymi głównie przez autochtonów, którzy wobec kryzysu ekonomicznego coraz niechętniej godzą się na ponoszenie tych obciążeń.

Imigranci są także konkurencją dla ludności miejscowej na rynku pracy, co powoduje rosnącą obawę o wzrost bezrobocia. Przestępczość i patologie społeczne są częstsze w społeczności napływowej zamieszkującej zwarte getta. Wszystkie te problemy mogą doprowadzić do radykalizacji postaw miejscowej ludności, która w skrajnych przypadkach może prowadzić do aktów terroru jakie miały miejsce w Norwegii na wyspie Utoya i w Oslo w 2011 roku. Z tych powodów autor chce ukazać wpływ imigrantów na życie społeczne i polityczne w Szwecji, Norwegii i Danii oraz przedstawić zagrożenia wynikających z napływu ludności. Przedstawienie różnic kulturowych powodujących problemy we wspólnej egzystencji imigrantów i autochtonów, a także zagrożenia związane z napływem pracowników i sytuacją mieszkaniową wśród imigrantów. Ważną sprawą będzie również radykalizacja poglądów na temat imigrantów w społeczeństwach państw skandynawskich i populizm partii politycznych w związku z tym zagadnieniem. Autor postara się przedstawić możliwości rozwiązania tych problemów, biorąc pod uwagę, że „u podstaw rozwiązywania najistotniejszych problemów bezpieczeństwa leży niewątpliwie ocena zagrożeń" ${ }^{4}$. Stanowią one podstawę do formułowania polityki w tym obszarze, a także zastanowić się nad liczbą i formą przyjmowania imigrantów, pokazując ewentualny związek trudności w integracji $\mathrm{z}$ ich krajem pochodzenia i kręgiem kulturowym. U podstaw rozwiązywania najistotniejszych problemów bezpieczeństwa leży niewątpliwie ocena wyzwań i zagrożeń. Stanowią one podstawę do formułowania polityki w tym obszarze.

\footnotetext{
${ }^{4}$ R. Olszewski, Bezpieczeństwo współczesnego świata, Toruń 2005, s. 9.
} 
Marcin Wysocki - Państwa skandynawskie wobec zagrożeń...

\section{Wpływ imigracji na bezpieczeństwo państw skandynawskich}

Artykuł podejmuje analizę wpływów imigracji ludności na bezpieczeństwo społeczne i polityczne państwa, korzystając z doświadczeń Królestwa Danii, Królestwa Szwecji i Królestwa Norwegii. Opisywane zjawisko, będzie miał coraz większy wpływ na społeczeństwa skandynawskie i całą Europę. Napływ obcej kulturowo ludności będzie miał zapewne pozytywne i negatywne skutki. Wartości liberalne Europy Zachodniej z jej multikulturalizmem, tolerancją i wolnościami obywatelskimi, które pozwalają na napływ imigrantów mogą w przyszłości doprowadzić do ich zachwiania. Poszanowanie tych zasad, szczególnie dostrzeganych w państwach skandynawskich, powinno spowodować zastanowienie się nad skutkami otwartej polityki imigracyjnej, sposobie integracji i rozwiązywaniem ewentualnych problemów.

Europa jest atrakcyjna dla imigrantów, ze względu na wyższe standardy życia niż w krajach ich pochodzenia. Wśród krajów europejskich popularnym kierunkiem migracji są państwa skandynawskie, które postrzegana są jako region bezpieczny i bogaty. Imigranci mają możliwość pracy, edukacji, lepszej opieki socjalnej i wolności obywatelskich, w tym religijnych. Państwa zachodniej Europy, w tym kraje skandynawskie stosowały po okresie II wojny światowej otwartą politykę wobec imigrantów, co ulega jednak zmianie wobec rosnących problemów. Wszystkie państwa europejskie potrzebują specjalistów i nastawiają się na przyjmowanie wykształconych pracowników. Kraje Unii Europejskiej stoją przed wyzwaniem starzejącego się społeczeństwa, który może zachwiać systemem ekonomicznym, jeżeli nie napłynie dostateczna siła robocza. Model państwa opiekuńczego, który występuje również w Skandynawii zakłada, że stosunek między ludnością $\mathrm{w}$ wieku produkcyjnym, a poprodukcyjnym wynosi 5 do 1 . Proporcje te zmieniły się w krajach europejskich na 4 do 1 , a w ciągu 50 lat prognozuje się spadek do dwóch osób pracujących, na jedną pobie- 
rającą emeryturę ${ }^{5}$ Wobec małej dzietności Europejczyków imigranci są potrzebni jako uzupełnienie niedoborów rynku pracy. Liczba imigrantów spoza krajów UE wynosi 35,1 mln, natomiast imigrantów z innego kraju UE wynosi 19,3 mln ${ }^{6}$. Jednak biorąc pod uwagę wielodzietny model rodziny ludności napływowej i dalszą imigrację, odsetek migrantów prawdopodobnie się zwiększy.

\subsection{Wielokulturowy wymiar społeczeństw skandynawskich}

Kraje skandynawskie przestrzegają wolności religijnej w swoim ustawodawstwie, prawo to jest zapisane w konstytucji Dani, Norwegii i Szwecji. Zwiększająca się liczba imigrantów stawia wymienione państwa przed zadaniem zapewnienia im odpowiednich warunków do kultywowania wyznawanych przez nich religii. Kolejnym wyzwaniem dla rządu jest budowanie relacji między państwem, a coraz liczniejszymi organizacjami religijnymi. Może to być problematyczne zwłaszcza w krajach posiadających kościół państwowy.

W Skandynawii panuje wyjątkowa specyfika państwa opiekuńczego $^{7}$. Najważniejszy nacisk $\mathrm{w}$ programie integracji kładzie się tam na uczestnictwo obcokrajowców w działalności społecznej państwa. System ten zakłada równość wszystkich obywateli oraz, że wszyscy mieszkańcy będą wspierać rozwój państwa poprzez podatki ${ }^{8}$. W zamian każdy takie same przywileje i obowiązki wobec kraju9. Dlatego model skandynawski wspiera uniwersalizm i ponowne rozdysponowanie środków w formie pomocy socjalnej. Równość obywateli w Skandynawii postrzegana jest zarazem w formie „podobieństwa kulturowego" i ,politycznej jedności”.

5 P. Scheffer, Druga ojczyzna: Imigranci w społeczeństwie otwartym, Wołowiec 2010, s. 141-142.

${ }^{6}$ Statystyka dotyczq̨a migracji i populacji migrantów, Eurostat Statistics Explained, http://ec.europa.eu/eurostat/statistics-explained/index.php?title=Migration_and _migrant_population_statistics/pl, [dostęp: 2-05-2018].

${ }^{7}$ A. Pawlik, Słownik wiedzy ekonomicznej, Kielce 2010, s. 240.

${ }^{8}$ A. Kowol, Wariant szwedzki ekonomii dobrobytu. Teoria i praktyka, s. 8-9, http://szwecja.adamkowol.info/, [dostęp: 2-05-2018].

9 J. Kubitsky, Alfabet szwedzki, Warszawa 2011, s. 84. 
Marcin Wysocki - Państwa skandynawskie wobec zagrożeń...

Społeczeństwa skandynawskie postrzegają załatwienie kwestii integracji jako domenę państwa. Wobec tego istnieją liczne przepisy prawne regulujące kwestie cudzoziemców (zagwarantowanie nauki języka, historii, wiedzy o społeczeństwie). Jednak nawet wobec dużej liczby przepisów integracja imigrantów i azylantów w państwach skandynawskich sprawia problemy. Etniczne społeczności charakteryzują się bowiem dużą jednorodnością, żyją oni w bliskich stosunkach i nie nawiązują szybko mocnych relacji z kulturowo obcą ludnością.

Kraje skandynawskie stosują praktycznie dwa sposoby integrowania obcokrajowców, wyróżniamy duński i szwedzki. Mają one znaczne różnice, mimo że oba mają podstawy w systemie pomocy społecznej. Królestwo Danii stara się doprowadzić do społeczności bardziej jednolitej kulturalnie i historycznie, natomiast Szwecja opiera się na idei multikulturalizmu. Działając w tym duchu, władze duńskie nie obdarzają mniejszości etnicznych, poza historycznymi (np. mniejszość niemiecka) prawami politycznymi. Inaczej postępują Szwedzi, którzy nadali, przykładowo, prawo do posiadania politycznych reprezentantów nierdzennej społeczności cygańskiej10. Państwa skandynawskie mają przed sobą wyzwanie zwiększenia zatrudnienia wśród cudzoziemców. Kwestia ta jest często podnoszona w debatach publicznych na temat integracji. Dlatego Skandynawia powoli zmienia politykę imigracyjną z bazującej na państwie opiekuńczym, w stronę koncepcji integracyjnych opartych na indywidualności i wolności.

Wobec niepewnych warunków bytowych w państwach pochodzenia imigrantów, model skandynawski wydaje się bardzo atrakcyjny dla nich. Niestabilna sytuacja społeczna, prześladowania, konflikty zewnętrzne lub wewnętrzne $\mathrm{w}$ krajach pochodzenie nie gwarantują podstawowych potrzeb socjalno-bytowych i poczucia bezpieczeństwa, nie mówiąc już o możliwościach rozwoju, natomiast poziom życia jest niewspółmiernie wyższy w Skandynawii.

10 Polityka migracyjna jako instrument promocji zatrudnienia i ograniczania bezrobocia, Ośrodek Badań nad Migracjami UW, Warszawa 2007, s. 14-15, http://mighealth. net/pl/images/3/36/Promocja_zatrudnienia.pdf, [dostęp: 2-05-2018]. 
Wolność religijna jest przestrzegana w krajach skandynawskich. Jednak w Danii i Norwegii uprzywilejowaną pozycję mają kościoły narodowe, będące jednocześnie częścią administracji państwowej. Mimo to sytuacja imigrantów z krajów muzułmańskich w kwestii praktyk religijnych wydaje się dobra. Dotyczy to muzułmanów, chrześcijan różnych obrządków, bahawitów oraz zaratusztrian etc. Posiadają własne miejsca kultu, są zazwyczaj uznawani i wspomagani przez państwo, a także mogą sprowadzać duchownych z zagranicy. Problemem może być opór społeczności lokalnych wobec zwiększających się liczby miejsc kultu ludności napływowej i postrzeganie kultywowania własnej religii jako przeszkody w integracji. Jeżeli rdzenne społeczności zaczną te wolności ograniczać może dojść do narastania, a w konsekwencji wybuchu niezadowolenia wśród imigrantów.

\subsection{Polityka społeczna $w$ państwach skandynawskich}

Kraje skandynawskie zapewniają świadczenia socjalne o poziomie pozwalającym na życie w minimalnych warunkach bytowych. Pozwala to na zapewnienie podstawowego bezpieczeństwa w sferze ekonomicznej dla osób legalnie mieszkających. Ponadto państwa te zapewniają świadczenia ubezpieczeniowe, których poziom zależy od wysokości wcześniejszych pensji. Takie warunki zachęcają imigrantów, zwłaszcza biorąc pod uwagę różnice w postrzeganiu minimum bezpieczeństwa socjalnego w Skandynawii z krajami pochodzenia.

Zasiłki dla osób bezrobotnych oparte są na tzw. modelu gandawskim. Opiera się on na zastosowaniu pierwszego poziomu podstawowego i kolejnego, który jest połączony z ubezpieczeniem. Związki zawodowe tworzą zakłady ubezpieczeniowe, które są wspierane przez rząd. Taki system ubezpieczeniowy nie obejmuje $w$ pełni pracowników nienależących do związków zawodowych, a także bez kontynuacji zatrudnienia. Wobec tego na wypadek bezrobocia państwo zabezpiecza wszystkich zatrudnionych poprzez podstawowy system. Jakub Wiśniewski stwierdził, że „[...] taka konstrukcja zasiłków dla bezrobotnych, oparta na komponencie ubezpieczeniowym, zmniejsza ryzy- 
Marcin Wysocki - Państwa skandynawskie wobec zagrożeń...

ko wyłudzania świadczeń w ramach „transgranicznej turystyki socjalnej". Model skandynawskiej polityki społecznej jest egalitarystyczny, dając większe znaczenie pierwszemu poziomowi system bezpieczeństwa socjalnego, niż w pozostałych rozwiniętych państwach europejskich. Obywatelstwo wystarcza do podstawowych usług medycznych i świadczeń emerytalnych, co wyróżnia Skandynawię od innych krajów, gdzie brana jest pod uwagę pozycja zawodowa. Skandynawski system socjalny charakteryzuje się również swoją powszechnością. Usługi socjalne dostępne są dla szerokiej rzeszy osób, w tym imigrantów i azylantów. Tak szeroki dostęp do świadczeń usługowych ma za zadanie walkę z zagrożeniami socjalnymi (np. pomoc osobom niepełnosprawnym), profilaktykę oraz integrację społeczeństwa, w tym imigrantów. Środki finansowe na te usługi pochodzą z lokalnych podatków. Daje to możliwość zastosowania odpowiednich działań socjalnych w zależności od możliwości i potrzeb danej społeczności. Poza tym rządy skandynawskie zwiększają zatrudnienie w administracji państwowej na obszarach występowania większego bezrobocia. Koszty takiej polityki społecznej pokrywa system podatkowy, który ponownie dystrybuuje pobrane środki od obywateli. „Dochód od osób fizycznych, konsumpcja i wzbogacenie są opodatkowane bardzo wysoko. Większość obywateli była do lat 90 . XX wieku objęta podatkiem dochodowym w wysokości przekraczającej 50\% (obecnie obciążenie podatkowe jest nieco niższe). Składki na ubezpieczenia społeczne płacone przez pracodawców sięgają 35\%, podczas gdy stawka podatku VAT wynosi $25 \%$ w odniesieniu do większości dóbr i usług. Kapitał i dochody przedsiębiorstw są opodatkowane bardzo umiarkowanie"11.

Kraje skandynawskie charakteryzowało przez długie lata bardzo szerokie zabezpieczenie bytu socjalnego, poprzez wysokie podstawowe zasiłki oraz dodatkowe pochodzące z ubezpieczeń. Nierestrykcyjne były również kryteria otrzymania świadczeń. Objawiało się to zwłaszcza w niedługim czasie karencji, możliwości wypłacania pomo-

${ }^{11}$ J. Wiśniewski, Mobilność pracowników i usług w regionie Morza Bałtyckiego, Biuletyn Analiz UKIE Nr 19, s. 2-5, https://www.msz.gov.pl/resource/33fa04e3d22f-43b3-a348-fab07b8c28f1:JCR, [dostęp: 2-05- 2018]. 
cy społecznej w długim okresie i spełnianiu liberalnych wymogów przyznawania zasiłków. Wobec takich warunków ich otrzymywania rozpoczęto społeczną dyskusję, którą spowodowało częste wyłudzanie środków socjalnych przez imigrantów w latach 90 . XX wieku. W jej wyniku nastąpiły zaostrzenia $\mathrm{w}$ ramach systemu pomocy omawianych krajów. Na skutek często naciąganego, korzystania imigrantów ze środków socjalnych zwiększa się niechęć pozostałych obywateli do pomocy socjalnej. Tym bardziej, że hojne zapomogi społeczne pochodzą z redystrybucji wysokich podatków. System usług medycznych i opiekuńczych wobec osób, które wyemigrowały do Skandynawii jest zasilany funduszami z samorządów, co również nie zadowala lokalnych społeczności. Zwłaszcza $w$ regionach dużych skupisk imigrantów.

Dla ludności napływowej system bezpieczeństwa społecznego w krajach skandynawskich jest bardzo atrakcyjny. Mimo zastosowanych w nim restrykcji i ograniczeń przyznawania pomocy społecznej w stosunku do kryterium potrzeby. Ubezpieczenia społeczne obejmujące większość obywateli powodują, że procent osób ubogich jest niski. Poziom bezrobocia daje możliwość znalezienia pracy przez imigrantów szczególnie w zawodach mniej elitarnych. Przedstawione czynniki bytowe zachęcają do wyemigrowania na teren Skandynawii. Jednak pogorszenie się koniunktury na rynku pracy spowodowane kryzysem ekonomicznym, powoduje obwinianie imigrantów za brak zatrudnienia. W państwach skandynawskich realizowane jest równouprawnienie kobiet i mężczyzn w kwestii zatrudnienia. Aby temu sprostać kobiety znajdują pracę głównie w administracji państwowej. Taki sam status obu płci dotyczy również wysokości wynagrodzenia i uprawnień w życiu społecznym ${ }^{12}$. Aktywność kobiet w społeczeństwie skandynawskim powoduje, że są to kraje pozwalające na realizację ambicji muzułmanek często dyskryminowanych we własnej oj-

12 J. Grzela, Równość płci jako fundament zrównoważonych społeczeństw nordyckich, s. 490-491, http://ptsm.edu.pl/wp-content/uploads/2016/01/ptsm-4-tom-2grzela.pdf [dostęp: 2-05-2018]. 
Marcin Wysocki - Państwa skandynawskie wobec zagrożeń...

czyźnie. Państwa skandynawskie pozwalają kobietom z państw islamskich na wykonywanie zawodów wcześniej im zakazanych i uczestnictwo w życiu publicznym.

Państwa dostosowują swoją politykę do zmieniającej się sytuacji demograficznej swoich krajów. Skandynawia jest bardzo otwarta na imigrantów. Jednak widać rosnące poczucie niepewności, zwłaszcza wobec napływu cudzoziemców z poza europejskiego kręgu kulturowego. Dlatego w krajach tych widać zaostrzenia w kwestii zdobycia zezwolenia na pobyt i pracę. Najbardziej widać ograniczenia w polityce imigracyjnej Danii, a najmniej Szwecji. Kraje skandynawskie starają się zintegrować już przybyłych imigrantów, w tym zachęcić ich do aktywnego udział w życiu społecznym, kulturalnym i zawodowym. Jednak integracja generuje koszty pokrywane przez państwo, a docelowo ogół obywateli. Rozbudowywane są instytucje zajmujące się imigrantami, prowadzone są zajęcia językowe i nauka o społeczeństwie, wspomagane są zrzeszenia imigranckie i wspólnoty religijne. Fundusze przeznaczane na ten cel są znaczne, a wobec kryzysu ekonomicznego może nastąpić zniechęcenie autochtonów. Skandynawia jest natomiast atrakcyjna dla imigrantów z krajów muzułmańskich. Mogą cieszyć się tu wolnością słowa i przekonań, mają zagwarantowaną pomoc socjalną i większe bezpieczeństwo niż w rodzimych krajach, często objętych konfliktami. Wobec cudzoziemców potrzebne są sprawne działania władz $w$ ramach mieszkalnictwa, zatrudnienia, bezpieczeństwa, rozwoju kultury i wreszcie wzajemnego zrozumienia.

Imigracja jest zjawiskiem pożądanym wobec zmniejszającej się dzietności w Skandynawii. Rodzi jednak sporo zagrożeń, dlatego potrzebne jest zastanowienie się nad jej formą i skalą. Ważne jest szerzenie tolerancji zarówno wśród rdzennej, jak i napływowej ludności. Tylko wówczas obje społeczności mogą wspólnie współżyć i doprowadzić do prawdziwej integracji w duchu pozytywnych wartości. 


\section{Zagrożenia społeczne i polityczne związane z imigracją}

Kultura jest bardzo ważnym czynnikiem kształtującym relacje pomiędzy przedstawicielami różnych społeczności. Społeczeństwa zachodnie dążą do westernizacji i uniwersalizacji wszystkich grup kulturowych, powodując tym opór, zwłaszcza wśród odmiennych obyczajowo społeczności. Przykładem wyzwań społecznych i politycznych jest imigracja społeczności muzułmańskiej, gdzie istnieje wiele różnorodnych kultur, jak np. arabska, turecka, perska i malajska. Łączy je wszystkie religia, która wyznacza większość aspektów życia. W kręgach europejskich występuje wyraźny rozdział strefy sacrum od strefy publicznej, a także większy nacisk na indywidualizm.

Według Samuela P. Huntingtona: „W całym świecie islamu lojalność obowiązywała przede wszystkim wobec małej grupy i wobec wielkiej religijnej wspólnoty, plemienia i ummy. Państwo narodowe mniej się liczyło"13. Ukazuje to różnicę w podejściu jakie mają Europejczycy wobec swoich państw narodowych. Kultura islamska postrzegana jest przez muzułmanów jak doskonalsza. Wychwalane są własne wartości i ostrzega się przed wpływami zepsutego zachodu. Mahometanie widzą zachodnią kulturę jako zepsutą, chylącą się ku upadkowi i nastawioną na konsumpcję. Obyczaje europejskie postrzegane są jednocześnie jako pociągające, co jeszcze powiększa strach przed nimi. Laickość i ateizm postrzegane są jako przyczyna braku moralności i wzbudza największą niechęć. Samo chrześcijaństwo jest uznawane za „religię Księgi”. Wyznawcy islamu mimo różnic politycznych i religijnych stwierdzają duże różnice w obyczajowości. Wobec niechęci muzułmanów, rośnie również poczucie zagrożenia islamem w Europie. Muzułmanin ma określone większość aspektów życia przez zasady religijne. Dlatego imigranci z kręgu kultury islamskiej tak trudno integrują się ze społecznościami skandynawskimi. Przekonanie muzułmanów o wyższości, łącznie z poczuciem amoralnego charakteru wartości europejskich pokazuje trudności w społecznej koegzystencji.

13 S. P. Huntington, Zderzenie cywilizacji, Warszawa 2001, s. 258-259. 
Marcin Wysocki - Państwa skandynawskie wobec zagrożeń...

Wiele wysiłku i starań musi być włożone, aby przekonać imigrantów z krajów islamskich o pozytywnych aspektach liberalnych idei skandynawskich.

Napływ odmiennych wyznaniowo imigrantów do środowiska demokratycznego i laickiego jest nowym doświadczeniem. Dochodzi do współżycia m. in. ateistów, muzułmanów, żydów oraz chrześcijan. Są różne możliwości zachowania wierzących imigrantów w społeczeństwie świeckim. Do głosu dochodzą grupy fundamentalne, liberalne i świeckie. Fundamentalizmowi religijnemu wśród imigrantów poświęca się dużo uwagi, ale są też społeczności reformujące się w stronę poszanowania wolności i równouprawnienia. Część wcześniej ortodoksyjnych religijnie imigrantów poddaje się również zeświecczeniu. W państwach laickich wiarę kultywuje się w swojej prywatnej sferze. Może to powodować niezadowolenie wierzących migrantów, jako że $\mathrm{w}$ większości religii odstępstwo od wiary jest surowo potępiane. Pozycja materialna ma również znaczenie, ponieważ w większości osoby o niepewnym statusie bardziej poszukują pomocy w Bogu, niż ci o zabezpieczonym bycie. Dlatego dużo imigrantów o gorszym statusie społecznym wraca do wartości ortodoksyjnych. Wśród części imigrantów dokonywany jest wybór między fundamentalizmem religijnym, a sekularyzacją. Przykładem są tu imigranci z krajów muzułmańskich, gdzie wpływ wierzących muzułmanów na mniej fundamentalnych jest duży. W skupiskach ludności islamskiej często wymuszane jest noszenie chust przez kobiety pod wpływem zastraszania. Poza tym mahometanin porzucający wiarę jest automatycznie wyrzucany ze społeczności. Dlatego rozmieszczenie muzułmanów w mniej zwartych grupach daje im możliwość wyboru. Główny konflikt między imigrantami, a autochtonami będzie dotyczył jednak wartości etycznych. Przykładem mogą być relacje między obiema płciami, homoseksualizm, kwestie życia rodzinnego i aborcja. W tych kwestiach różnice między zasadami kręgu kultury islamskiej, a wartościami zsekularyzowanych, demokratycznych społeczeństw europejskich są duże. Dochodzi do ich pogłębiania wobec szybkich liberalnych reform. Imigrantów sprzeczności te dotykają jeszcze mocniej, ponieważ mają możliwość zobaczyć 
inne wzorce. Równouprawnienie kobiet i mężczyzna, jest nieadekwatne w kulturze muzułmańskiej. Same kobiety często mówiąc o ilości dzieci wyliczają tylko chłopców. Konserwatywne wzorce nierzadko pogłębiają frustracje seksualną w społeczności imigranckiej, która mierzy się z wolnością obyczajów. Młodzież imigrancka jest obarczana dylematami w jaki sposób zachowywać się wobec otaczającej ją odmiennej rzeczywistości. Jeżeli młodzi ludzie ze społeczeństwa napływowego nie uczestniczą w życiu grupowym na równi z resztą rówieśników zostają wyalienowani. Homoseksualizm jest również mocno potępiany $\mathrm{w}$ świecie islamskim. Wiele wysiłku jest potrzebne, aby ujednolicić postrzeganie tak ważnych spraw jak np. rodzina. Konserwatywne zwyczaje kulturalne, często usprawiedliwia się względami religijnymi. Wymieszanie wiary i kultury jest bardzo silne. Przykładowo nadrzędne miejsce mężczyzny w kulturze islamu jest również akcentowane $w$ innych tradycjach. Jednak w Koranie występuje duże usankcjonowanie takiego stanu rzeczy. Noszenie chusty na głowie jest traktowane przez niektórych jako przykład podległości kobiety. Kwestia zezwolenia lub zakazania tego zwyczaju budzi duże kontrowersje również wśród społeczeństw skandynawskich. Państwo powinno zezwalać na głoszenie różnych poglądów w imię wolności słowa, jednak nigdy sprzecznych z podstawowymi wartościami jak wolność czy równość. Taki stan rzeczy nie zadowoli jednak fundamentalnych środowisk muzułmańskich dążących do szerokiego zaakceptowania ich zasad. Imigracja doprowadza do spotkania różnych kultur. Wywołuje to nieporozumienia, które wymagają zdecydowanych działań.

Paul Scheffer napisał, że: „Na przykład, chociaż często podkreśla się „inherentną wartość zwyczajów i obyczajów”, kompromis w sprawie tradycji zawierania przymusowych małżeństw jest niemożliwy"14. Dlatego w kwestiach fundamentalnych wolności trzeba przyjąć twardą retorykę. Mimo, że podejście wielokulturowości nadal dominuje w krajach skandynawskich, to widać zmianę sposobu podejścia do integracji. Multikulturalizm postrzega każdą grupę etniczną jako od-

14 P. Scheffer Druga ojczyzna. Imigranci..., op. cit., s. 341. 
Marcin Wysocki - Państwa skandynawskie wobec zagrożeń...

dzielne grono. Powoduje to różne ocenianie obyczajów. Taki sam sposób życia w odmiennych warunkach powoduje narastanie problemów. Tworzenie jednolitego społeczeństwa ma podstawy w krajach o rozbudowanej pomocy socjalnej. Mieszkańcy mają wtedy świadomość, że pomagają poprzez redystrybucję podatków członkom własnej grupy. Kolejnym zagrożeniem idei wielokulturowości jest zaniechanie nauki historii państwa przyjmującego. Nie mówi się o tym co spowodowało powstanie społeczeństwa otwartego na imigrantów. Pojawienie się imigrantów w końcu również dla autochtonów wprowadza wiele zmian w obyczajach. Następnym problematycznym zagadnieniem jest przyznanie specjalnych praw grupą kulturowym. Aby mogły kultywować własne tradycje według systemu np. opartego na szariacie. Kto wtedy określa przynależność do danej społeczności? Poza tym jak wówczas zapewnić ochronę prawną muzułmańskim kobietom. Wydaje się, że pełen multikulturalizm ma słuszność, jeżeli zakładamy powrót społeczności imigranckiej do kraju pochodzenia. Wtedy edukacja dzieci w tradycji i języku przodków ma sens. Aby rozwijać całe społeczeństwo należy zaszczepić wspólne normy potrzebne w liberalnym świecie. Pomoże to rozwiązywać nieporozumienie. „Jeśli nie ma się wspólnych norm prawnych, wspólnych świąt, wspólnych norm w odniesieniu do sukcesów w szkole, równych szans w zdobywaniu pracy ani wspólnej historii, wówczas kurczy się możliwość pożytecznej wymiany poglądów, a wzrasta pole do nieporozumień" 15 .

Imigracja powoduje w dużej mierze napływ taniej siły roboczej. Jednak wobec dłuższego okresu pobytu słabo wykształceni cudzoziemcy stanowią obciążenie. Firmy nie muszą inwestować w technologię, nierentowne przedsiębiorstwa utrzymują się na rynku ze względu na tanich pracowników. Poza tym zatrudniani są słabiej opłacani imigranci niż rdzenna ludność. Cudzoziemcy o niskich kwalifikacjach mogą liczyć na pomoc państwa opiekuńczego, co jest zachęcające do przyjazdu. System powinien być tak zmieniony, aby z prawami socjalny szły w parze obowiązki wobec państwa.

15 Ibidem, s. 350. 
Możliwość uzyskania zatrudnienia jest mniejsza w przypadku cudzoziemców niż miejscowej ludności. W przypadku rozwoju gospodarczego coraz więcej imigrantów znajduje pracę, natomiast w chwili kryzysu w pierwszej kolejności zwalniani są cudzoziemcy. Przykładowo w Szwecji, wykształceni imigranci głównie nie są zatrudnieni w swoich branżach. Sytuacja taka spowodowana jest częściowo z braku odpowiednich sposobów sprawdzenia wiedzy. Kolejną przyczyną jest słabe respektowanie odmiennych systemów edukacji. Wymaga, aby nastąpiło zacieśnienie współpracy instytucji kształcących w Szwecji z ich odpowiednikami w krajach pochodzenia migrantów. Problem nasila się wśród młodzieży imigranckiej, a w szczególności mężczyzn, z których ok. 20-30\% kończy naukę na gimnazjum i nie szuka dalszego zatrudnienia. Niepokojące jest, że są wśród nich osoby przebywające w Szwecji nawet 10 lat. Istotne jest, że ok. 50\% z nich nie zapisało się do agencji pośrednictwa w celu znalezienia pracy ${ }^{16}$. Powodem małego zaangażowania młodych imigrantów na rynku pracy jest ograniczanie się do życia we własnej, po części odizolowanej społeczności. Nierzadko taką sytuacje powodują trudności w przystosowaniu się w nowym środowisku. Wobec tych problemów stosuje się motywowanie imigrantów. Dofinansowuje się miejsca pracy dla najmniej wykwalifikowanych cudzoziemców oraz daje się im możliwość podnoszenia doświadczenia zawodowego poprzez kursy łączone z pracą. Mały udział w rynku pracy imigrantów powoduje ich zależność od zasiłków socjalnych. Pomoc społeczna obejmuje obcokrajowców, głównie z państw Afryki Północnej i Bliskiego Wschodu w stosunkowo większej mierze, niż ludność miejscową. Zdarza się, że pobieranie pomocy państwa trwa bardzo długi czas i imigrant się od niej uzależnia nie próbując znaleźć pracy. Specyfiką jest, że odbiorcą zapomóg wśród społeczności imigranckiej są głównie rodziny, gdy wśród rdzennej społeczności to samotni mężczyźni. Najważniejszym

\footnotetext{
${ }^{16}$ M. Banaś, Wielość kultur, różnorodność tradycji, jedno społeczeństwo. Szwedzki model polityki integracyjnej, Instytut Studiów Regionalnych UJ, s. 16-21, http://www. isr.wsmip.uj.edu.pl/documents/3337228/64d5af4d-167e-4f49-bf92-120135d1a1df, [dostęp: 2-05-2018].
} 
Marcin Wysocki - Państwa skandynawskie wobec zagrożeń...

celem państwa jest więc zachęcenie cudzoziemców do aktywnego udziały na rynku pracy. Przykład Szwecji udowadnia, że aby tego dokonać, trzeba przeprowadzić akcję informacyjną i edukacyjną na wielu poziomach. Mobilizacja osób chronicznie uzależnionych od zasiłków jest trudna, ale możliwa i potrzebna ${ }^{17}$. Uświadamianie zalet posiadania zatrudnienia i własnych zarobków powinno być prowadzone od najmłodszych lat. Udowodniono, że prościej jest dla imigrantów założyć własną działalność. Jednak trzeba by było zainwestować duże fundusze $\mathrm{w}$ program informujący $\mathrm{m}$. in. o sposobach prowadzenia firmy, pomoc w kwestiach biurokratycznych.

Problem integracji imigrantów i poziomu ich życia wiąże się z edukacją. Mimo rozwoju szkolnictwa i rozwoju edukacji dla imigranckich uczniów nie zwiększa się ich wykształcenie w takim stopniu, jak w przypadku dzieci rdzennej ludności. Wiele cudzoziemskich kobiet nie kończy podstawowych klas. Wśród mężczyzn również widać inny poziom edukacji. Obowiązki w domu są ważniejsze dla wielu dziewcząt zwłaszcza pochodzących z państw Afryki i Bliskiego Wschodu. Rzadziej rozwijają swoje wykształcenie, co wiąże się z obyczajami i rolą kobiety w muzułmańskim systemie. Natomiast mężczyźni nie są odpowiednio zachęcani przez rodzinę, aby rozwijać swoją edukację. Często zmiana otoczenia doprowadza do problemów w nauce z powodu ciężaru aklimatyzacji. „Opuszczenie rodzinnego kraju, nawet jeśli dobrowolne, może pociągać za sobą często nieuświadomiony przez jednostkę stres wynikający z wysiłku adaptacji do nowych realiów, próby zrozumienia nowej rzeczywistości oraz opanowania podstawowych kompetencji do poruszania się w nowej, początkowo całkiem obcej kulturze"18. Czynniki zdrowotne mają duży wpływ na udaną integracje i życie, a także przydatność dla społeczeństwa. Duża część, głównie azylantów ma problemy ze zdrowiem, zwłaszcza natury psychicznej po zmianie miejsca pobytu. Sami imigranci słabo oceniają

\footnotetext{
${ }^{17}$ K. Zawadzki, Szwecja i Dania, [w.] Z. Wiśniewski (red.), K. Zawadzki (red.), Aktywna polityka rynku pracy w Polsce w kontekście europejskim, Toruń 2010, s. 181189.

18 M. Banaś, Wielość kultur, różnorodność..., op. cit., s. 20.
} 
swoje samopoczucie z medycznego punktu widzenia. Brakuje im pewności siebie wobec otaczającego ich świata. W takich przypadkach zapewniane jest leczenie i pomoc psychologiczna, łączona często z podnoszeniem kwalifikacji pracowniczych.

W Norwegii sytuacja na rynku pracy spowodowała debatę o imigrantach, którzy w dużej mierze pracują za niższą stawkę niż rodowici mieszkańcy. Powoduje to spadek poziomu płac i formę współzawodnictwa. Z drugiej strony imigracja zapewnia dostęp do dużej liczby pracowników, którzy z kolei tworzą nowe zapotrzebowanie na rynku. Przykładowo norweskie władze planują zrównanie zarobków dla osób w danej branży, co obniży zarobki wielu pracownikom. Dobrą pozycje na rynku pracy mają przedstawiciele imigrantów muzułmańskich z Europy. W Norwegii to np. Bośniacy. Kończą oni często studia i mają pracę na podobnych stanowiskach co rdzenna ludność. Stałe miejsce pracy ma ok. $60 \%$ osób pochodzących z Bośni, bez względu na płeć. Tylko $8 \% \mathrm{z}$ nich jest zapisanych jako nieposiadających zatrudnienia. Pakistańczycy, Irakijczycy, Somalijczycy i Kurdowi mają procentowo słaby udział na rynku pracy. Największe bezrobocie wśród imigrantów dotyka tych z Somalii, ze względu na krótki okres pobytu. Mężczyźni stanowią znacznie więcej zatrudnionych aniżeli kobiety. Imigranci z Pakistanu pracę znajdują głównie w transporcie, hotelarstwie i gastronomii. Pakistańczycy urodzeni już w Norwegii posiadają często wyższe wykształcenie. Aż 5\% imigrantów pakistańskich posiada własne przedsiębiorstwo. Jest to największa liczba z pośród napływowych społeczeństw etnicznych ${ }^{19}$.

W krajach skandynawskich spotykana jest dyskryminacja w pracy ze względu na pochodzenie etniczne lub wyznanie. W Szwecji wielu zagranicznych pracowników sezonowych pracuje w bardzo trudnych warunkach, dochodzi do zabierania paszportów, zatrzymania wypłat oraz niezapewniania dobrych warunków socjalnych. Wytyczne Szwedzkiej Federacji ds. Handlu Detalicznego i Żywności obejmują

${ }^{19} \mathrm{~K}$. Lewandowska, Tematyka imigracyjna $w$ literaturze norweskiej od połowy lat 80-tych XX wieku, Poznań 2010, s. 41-51. 
Marcin Wysocki - Państwa skandynawskie wobec zagrożeń...

obywateli UE, którzy pracują sezonowo w kraju, ale nie pracowników spoza UE20. W Danii nie było odnotowywanych przypadków dyskryminacji w pracy ze względu na pochodzenie etniczne lub wyznanie ${ }^{21}$.

Zaangażowanie imigrantów na rynku pracy jest bardzo ważne. Dlatego, że jego brak powoduje negatywne skutki finansowe dla państwa oraz gospodarki narodowej22. Społeczeństwa skandynawskie również nie będą tolerowały takie stanu rzeczy, zwłaszcza w połączeniu z pomocą socjalną. Taki stan będzie prowadził do narastania konfliktów i uprzedzeń. Poza tym brak pracy pogarsza warunki bytowe imigrantów, wywołując ich frustracje i hamuje integrację.

Zmiana miejsca zamieszkania bardzo wpływa na imigranta. Tym bardziej, że duża grupa z nich nie tylko zmienia kraj, ale również sposób życia. Często łącznie ze zmianą mieszkania w tradycyjnej wsi na nowoczesne miasto. Dlatego ma to duży wpływ na człowieka oraz nierzadko powoduje różne problemy. Uwarunkowania te wspomagają powstaniu enklaw etnicznych, gdzie kultywowane są dawne zwyczaje, gdzie ludność żyje w połączeniu rożnych systemów wartości. Wielokrotnie duże trudności sprawiają przenosiny ze wsi do miasta we własnym kraju, a co dopiero w obcym. W tradycjach społecznościach grupa jest na pierwszym miejscu, a indywidualizm nie jest wyraźnie obecny.

Skupianie imigrantów ma zazwyczaj miejsce na osiedlach będących skupiskami biedy i przestępczości. Migranci którym polepszy się stopa życiowa opuszczają je i znajdują sobie miejsce w bogatszych i bezpieczniejszych dzielnicach. Nowoprzybyła ludność napływowa zamieszkuje tzw. dzielnice ubóstwa. Nie daje to im motywacji do integracji. Cudzoziemcy osiedlają się w częściach miast z budownictwem

${ }^{20}$ Country Reports on Human Rights Practices for 2017 - Sweden, Department of State: Bureau of Democracy, Human Rights and Labor, https://www.state.gov/j/drl/ rls/hrrpt/humanrightsreport/index.htm?year=2017\&dlid=277159, [dostęp: 2-05-2018].

21 Country Reports on Human Rights Practices for 2017 - Denmark, Department of State: Bureau of Democracy, Human Rights and Labor, https://www.state.gov/j/drl/ $\mathrm{rls} / \mathrm{hrrpt} /$ humanrightsreport/index.htm?year=2017\&dlid=277159, [dostęp: 2-05-2018].

22 W. Lieder, Oświata w szwedzkim modelu państwa opiekuńczego, [w.] W. Anioł (red.), Analizy Norden Centrum, nr 1 (21), Warszawa 2014, s. 11-12. 
socjalnym. Wiąże się to głównie z ich statusem materialnym, ale również z chęcią zamieszkania wśród podobnej sobie grupy. Autochtoni bardzo niechętnie żyją w sąsiedztwie obcokrajowców. Powstawanie etnicznych enklaw zmniejsza napięcia między różnymi społecznościami i daje poczucie wspólnoty z innymi imigrantami. Jednak zbyt duże zamknięcie się wśród własnej grupy rodzi konflikty. Kultywowane są własne zwyczaje niezgodne z założeniami ogółu. Segregacja powoduje spowolnienie integracji kulturowej, społecznej i ekonomicznej. Mieszkanie w dzielnicy imigranckiej daje mniej możliwości poprawy sytuacji bytowej. Charakteryzuje je bieda oraz patologie społeczne oraz rodzinne. Powstaje świat, w którym nie ma warunków do rozwoju i trzeba walczyć o przeżycie. Imigranci w takich gettach są wyobcowani. Osoby tam zamknięte nie mogą decydować o swoim życiu, gdyż wpływ na nie wywiera otoczenie. Zamykanie się społeczności imigranckiej, rozwijającej się w innym środowisku, może doprowadzić do wybuchu konfliktów. Życie na granicy ubóstwa doprowadza do wrogości. Środowiska religijne mają w tym wypadku dużo do zaoferowania, gdy ani rodzina, ani instytucje państwowe nie proponują rozwiązań. Zanikają wartości rodzinne poprzez brak autorytetu odczuwanego w stosunku do rodziców, którzy często poprzez braki językowe są uzależnieni od dzieci. Nisko płatna praca powoduje, że część imigrantów uważa się za ofiary wyzysku. Udział w swoim społeczeństwie daje poczucie siły, która może się obrócić przeciw ludności rdzennej, dając upust frustracji.

Przykład Szwecji ukazuje, że ok. 25\% imigrantów posiada dom lub mieszkanie własnościowe, podczas gdy u autochtonów średnia ta wynosi ponad 50\%. Ludność napływowa wynajmuje głównie mieszkania w dzielnicach zamieszkałych głównie przez innych cudzoziemców. Szwedzki Urząd ds. Mieszkalnictwa ogłosił, że imigranci częściej mieszkają w za małych lokalach w stosunku do stanu osobowego ${ }^{23}$. Takie warunki wpływają na pogorszenie stosunków rodzinnych i jakości życia pojedynczych osób. Przyczyną takiego stanu rzeczy jest

${ }^{23}$ M. Banaś, Wielość kultur, różnorodność..., op. cit., s. 18-20. 
Marcin Wysocki - Państwa skandynawskie wobec zagrożeń...

oszczędzanie, poprzez wynajęcie małego mieszkania na duża liczbę osób. Dzieci żyjące w takich warunkach mają gorsze warunki, a docelowo wyniki w nauce. Brak własnej przestrzeni powoduje trudności w zdobywaniu wiedzy. Wskazana byłaby budowa obszerniejszych lokalów mieszkalnych. Takie rozwiązuje generuje jednak koszty, które obciążyłyby państwo już przeznaczające duże sumy na imigrantów. Należy również podkreślić, że enklawy etniczne mają wysoki odsetek przestępczości.

Zmiana takiego stanu rzeczy jest długotrwała, wymagająca nakładów finansowych oraz działań społecznych. Tym bardziej, że segregacja ma zarazem przyczyny kulturowe oraz majątkowe. Samorządy starając się uporządkować sytuację gett pokazują, że mieszkańcy autochtoniczni sami próbują załatwić dręczące ich problemy, bez władz ogólnopaństwowych. Rozwiązaniem może być mieszanie bloków socjalnych, z tymi o własnościowym charakterze, aby doprowadzić do wymieszania się społeczeństw. Jednak przeszkodą jest brak poparcia rdzennej ludności chcących zapewnić sobie bezpieczeństwo, przed kojarzonymi z przestępczością imigrantami. Mieszkalnictwo jest jednym z ważniejszych wyzwań oraz aspektów integracji, a jego zaniedbanie może doprowadzić do konfliktów. Dlatego trzeba powiększać poczucie utożsamiania się ze swoim miejscem zamieszkania m.in. poprzez zaangażowanie wydarzeń kulturalnych. Aby społeczność miasta $\mathrm{z}$ dużym odsetkiem imigrantów stopiła się w całość. Należy wskazać, że jest to dla państw skandynawskich wyzwanie, które przy braku odpowiedniej reakcji stanie się zagrożeniem dla bezpieczeństwa.

Państwa skandynawskie próbowały narzucić rozproszenie odgórnie. W tej chwili stosuje to wyłącznie Dania, a Szwecja tylko wobec uchodźców. Wiążę się to z chęcią walki z etnicznymi enklawami, które utrudniają integrację, pogarszają status ich mieszkańców i wpływają negatywnie na bezpieczeństwo całej aglomeracji. Walka z problemem gett będzie kosztowna i trzeba przekonać do niej całe społeczeństwo. Budowa nowych mieszkań i zmniejszenie udziału lokali wynajmowanych na rzecz własnościowych. Poprawa tych standardów jest ważna, 
aby nie doprowadzić do wybuchów społecznych zamieszek w miastach skandynawskich. Królestwo Danii umiejętnie poradziło sobie z problemem enklaw imigranckich. W momencie, gdy osoba otrzyma status uchodźcy i zezwolenie na stały pobyt jest zobowiązana do przebywania w przydzielonej gminie. Obowiązek ten nałożony jest na co najmniej trzy lata, a gdy nie wywiązuje się z niego musi zrezygnować ze wszystkich świadczeń. Opiekę nad uchodźcą w tym czasie sprawuje wyznaczona gmina zgodnie z systemem podziału uchodźców, zapewnia mu mieszkanie i edukację. Okres obowiązkowej lokacji zależny jest od postępów w integracji ${ }^{24}$.

\subsection{Zagrożenie radykalizacji poglądów w społeczeństwach skandynawskich}

W społeczeństwie imigrantów, zwłaszcza z państw islamskich widać skłonności do radykalnych poglądów, których następstwem może być agresja. Występują religijne wątpliwości wobec wartości europejskich, jak i przemoc polityczna, również zastawiająca się dogmatami religii. Nie wszyscy popierają proces integrowania społeczności imigranckiej i rdzennej. Przyjmowanie liberalnych zasad lub nawet ich tolerancja jest utożsamiana przez część imigrantów jako zdrada ideałów. Jest grupa duchownych islamskich zniechęcających swoich współwyznawców do zacieśniania relacji z ogółem ludności. Islam jest w większości wyznawany konserwatywnie, a wyobcowanie zwiększa utożsamianie się z jego zasadami. Napędza to poczucie, że wiarę islamską próbuje się zniszczyć. Społeczeństwo muzułmańskie często identyfikuje się z ginącymi współwyznawcami palestyńskimi, czeczeńskimi, irakijskimi i afgańskimi. Skrajne poglądy powodują szerzenie się agresji. Wiele młodych osób samo wybiera tę drogę jako sposób rozwiązania otaczających go problemów. „W terroryzmie tkwi logika, którą warto dojrzeć. Mianowicie przemoc, wywieraną w anoni-

${ }^{24}$ Country Reports on Human Rights Practices for 2017 - Denmark, Department of State: Bureau of Democracy, Human Rights and Labor, https://www.state.gov/j/drl/ rls/hrrpt/humanrightsreport/index.htm?year=2017\&dlid=277159, [dostęp: 2-05-2018]. 
Marcin Wysocki - Państwa skandynawskie wobec zagrożeń...

mowy sposób przez Zachód na świat muzułmański, należy przenieść na ulice zachodnich miast; jest to jedyny sposób spowodowania zmian"25. Prowadzi to do umotywowania agresji jako słusznej. Bunt wywołuje zachwianie relacji rodzinnych oraz poczucie wyobcowania. Młodzież odnajduje tożsamość w religii. Integrację przedstawia się jako próbę zniszczenia ich kultury i wartości. W wyniku takiej propagandy, ten proces społeczny zostaje być postrzegany wśród migrantów jako negatywny, a nawet wrogi. Przemoc ma za zadanie nie tyle grożenie innym społecznościom, ale bardziej społecznością wewnętrznym imigrantów. Muszą oni liczyć, że w chwili akceptacji liberalnych wartości, wyrzekają się swojej przynależności religijnej lub etnicznej. Myślenie takie zakłada, że nie można się zintegrować ze społeczeństwem europejskim i jednocześnie zachować wiarę. Walka z terroryzmem nie powinna być konfliktem z religią. Władza powinna zapewnić bezpieczeństwo $\mathrm{w}$ razie ataku fundamentalistów. Imigranci muszą wiedzieć, że mogą na państwo liczyć i jednocześnie sami przeciwstawiać się przemocy. Występują również środowiska religijne, które chcą reform w duchu tolerancji. Uważają, że wiara jest wyznacznikiem, który określa drogę, ale jej rozumienie jest zależne od czasu w jakim przyszło żyć26.

Konflikty w świecie mają swoje udział w społeczeństwach skandynawskich. W Szwecji częste są antysemickie i antychrześcijańskie zachowania ze strony fundamentalnych mahometan oraz antysemickie i antymuzułmańskie ze strony środowisk ksenofobicznych. Ogólnie w tym kraju zostało zgłoszonych ok. 1177 przypadków przestępstw na tle religijnym. W 2016 roku najwięcej - 37\% było ich przeciw muzułmanom, następnie 25\% przeciw żydom, 25\% przeciw chrześcijanom, a $13 \%$ wobec pozostałych wyznań. Najbardziej powszechną formą było szerzenie nienawiści w Internecie lub poprzez graffiti, groźby, akty przemocy bezpośredniej w tym przemocy seksualnej. Przestępstwa o charakterze antychrześcijańskim miały miejsce głów-

\footnotetext{
25 P. Scheffer, Druga ojczyzna. Imigranci..., op. cit., s. 462-483.

26 Ibidem, s. 462-483.
} 
nie w ośrodkach dla uchodźców i azylantów. Liczba zachowań antysemickich wzrosła w związku z interwencja Izraela w strefie Gazy oraz ogłoszeniem Jerozolimy za stolicę Izraela przez USA. Większość $\mathrm{z}$ nich miała miejsce w najludniejszych miastach, tj. Sztokholmie, Malmö i Göteborgu. Biali rasiści organizowali marsze antysemickie i antymuzułmańskie w miastach szwedzkich. Zgłaszane były przypadki dyskryminacji w pracy ze względu na pochodzenie etniczne i religijne. W Szwecji mają miejsce również manifestacje neonazistów m. in. z okazji urodzin Adolfa Hitlera lub żydowskiego święta Jom Kippur. Należy nadmienić, że w Szwecji nie ma zakazu działalności organizacji neonazistowskich. W Göteborgu miała miejsce taka demonstracja oraz kontrdemonstracja w 2016 roku, a strony rozdzielała policja ${ }^{27}$. W Danii występują napięcia pomiędzy coraz liczebniejszą młodzieżą imigrancką z państw muzułmańskich, a młodzieżą duńską. Dochodzi tam głównie do wyzwisk i wandalizmów. Mają miejsce również napięcia między grupami żydowskimi, a muzułmańskimi. W 2016 roku miała miejsce planowanie zamachu terrorystycznego przeciw dwóm szkołom, w tym jednej żydowskiej przez 17-letnią Dunkę ${ }^{28}$. Konflikty etniczne i religijne mają miejsce również w Norwegii ${ }^{29}$. Spowodowane jest to brakiem strategii pozwalającej na udaną integracje i wzajemne zrozumienie różnorodnych grup społecznych. Jak szybko może dojść do społecznych niepokojów zainicjowanych przez mniejszość muzułmańską uświadomiły Skandynawii karykatury Mahometa opublikowane 30 września 2005 roku przez duński ,Jyllands-Posten”.

Zagrożeniem jest też radykalizacja rdzennych społeczeństw skandynawskich. Ponieważ co pewien okres mają miejsce próby zebrania

27 International Religious Freedom Report 2017: Sweden, Department of State: Bureau of Democracy, Human Rights, and Labor, https://www.state.gov/j/drl/rls/ irf/ religiousfreedom/index.htm?year=2017\&dlid=280964, [dostęp: 2-05-2018].

${ }^{28}$ International Religious Freedom Report 2017: Denmark, Department of State: Bureau of Democracy, Human Rights, and Labor, https://www.state.gov/j/drl/rls/ irf/religiousfreedom/index.htm?year=2017\&dlid=280900, [dostęp: $2-05-2018$ ].

${ }^{29}$ International Religious Freedom Report 2017: Norway, Department of State: Bureau of Democracy, Human Rights, and Labor, https://www.state.gov/j/drl/rls/ irf/religiousfreedom/index.htm?year=2017\&dlid=280944, [dostęp: $2-05-2018$ ]. 
Marcin Wysocki - Państwa skandynawskie wobec zagrożeń...

wsparcia wyborczego na niechęci wobec imigrantów. Partie prawicowe i populistyczne starają się zebrać na nim poparcie i zyskują uznanie w pewnych kręgach. W Szwecji jest to Nowa Demokracja, a Danii Duńska Partia Ludowa, a w Norwegii - Partia Postępu. Przykładem jak niebezpieczna mogą być radykalne poglądy są zamachy w Królestwie Norwegii z 22 lipca 2010r. Zginęło w nich 77 osób. Sposób w jaki do nich doszło wskazywał na członków organizacji typu ISIS. Winnym jest obywatel Norwegii, który określił użycie przemocy jako odpowiedź na zbyt otwartą politykę imigracyjną. Atak terrorystyczny nie był przewidywany lub brany pod uwagę przez Policyjną Służbę Bezpieczeństwa, zwalczającej terroryzm w Norwegii. Instytucja zajmowała się głównie zagadnieniami związanymi ze zwalczaniem fundamentalizmu muzułmańskiego. Zagrożenie ze strony prawicowego terroryzmu uznawane było za nikłe, jednak z początkiem XXI wieku zwiększa się liczba zagrożeń wynikających z działań skrajnych środowisk antyimigracyjnych. Ujawnia się to poprzez podpalanie, niszczenie miejsc kultu, cmentarzy, szkół należących do ludności napływowej oraz poprzez akty przemocy wobec ich przedstawicieli. Rasizm i ksenofobia mogą doprowadzić do ataków prawicowych fundamentalistów współpracujących na forum międzynarodowym. Zwiększenie obserwacji tych środowisk, może spowodować mniejszą infiltracje terrorystów islamskich. Nie należy jednak zapominać o zagrożeniu ze strony fundamentalistów islamskich. Zaistniała sytuacja pokazuje trudności w integracji cudzoziemców w jednonarodowym społeczeństwie. Wydaje się, że zmusi to siły polityczne to zaproponowania konkretnych kroków w ramach poprawy polityki migracyjnej. Zmianę widać w polityce Szwecji, która przyjmuje największą liczbę imigrantów, uchodźców i azylantów wśród omawianych państw skandynawskich. Rząd proponuje pomoc finansową dla osób dobrowolnie chcących powrócić do kraju pochodzenia w wysokości 3500 dolarów amerykańskich na osobę dorosłą i 1700 dolarów na dziecko (maksymalnie 8700 dolarów na rodzinę) ${ }^{30}$.

30 Country Reports on Human Rights Practices for 2017 - Sweden, Department of 
Państwa skandynawskie potrzebują znaleźć własną drogę aby dokonać udanej integracji. Trzeba będzie jednak $\mathrm{z}$ pewnych zasad zrezygnować, by inne zyskać, przy tym powinno się pamiętać o stosowaniu tych samych kryteriów wobec ludności imigranckiej i rdzennej. Dla udanej koegzystencji obu społeczności ważne będzie oddzielenie polityki od religii. Ortodoksyjne zasady religijne nie poddadzą się łatwo i szybko liberalnym reformą. Dlatego trzeba wyraźnie dążyć do oddzielenia państwa od religii. Rozdział powinien się opierać na ochronie instytucji publicznych przed wpływami religijnymi, ale i zapobiegać mieszaniu się państwa $\mathrm{w}$ kwestie wiary. Jeżeli nie wiąże się to $\mathrm{z}$ łamaniem prawa i nawoływaniem do nienawiści. Uprzywilejowana pozycja kościołów narodowych w Danii i Norwegii nie daje pełnej niezależności obu sfer. Imigranci muszą widzieć, że same państwo szanuje wolność religijną. Jednak trzeba przy tym pamiętać, że nie chodzi o zabronienie kultywowania wierzeń $\mathrm{w}$ społeczeństwie. Aktywny udział w życiu religijnym nie kuci się z aktywnością w życiu społecznym. Problem politycznego radykalizmu religijnego łączy się z poczuciem wyalienowania. Wolność wyznania jest podstawowym czynnikiem do udanego współżycia obu społeczności. Część fundamentalnych gryp religijnych uważa, że ich wartości religijnych nie da się pogodzić z zasadami wolnościowymi. Wśród nich widać jednak oznaki zeświecczenia, jak i pogłębiania wiary. Na temat religii można debatować, a nawet wyrażać o niej nieprzychylne poglądy. Kraje europejskie muszą dążyć do integracji społeczeństw, aby nie być zakładnikiem mniejszości. Podejmowane są próby przenoszenia konfliktów ideologicznych i religijnych z krajów pochodzenia imigrantów do najbliższego otoczenia państwa przyjmującego. Jednak przykład afery wokół duńskich karykatur Mahometa uświadamia, że sposób postrzegania świata przez społeczność imigrancką zaczyna odbiegać od poglądów muzułmanów w krajach islamskich. To właśnie m. in. w Damaszku i Bejrucie dochodziło do zamieszek po tamtych wydarzeniach.

State: Bureau of Democracy, Human Rights and Labor, https://www.state.gov/j/drl/ rls/hrrpt/humanrightsreport/index.htm?year=2017\&dlid=277159, [dostęp: 2-05-2018]. 
Marcin Wysocki - Państwa skandynawskie wobec zagrożeń...

Integracja jest powiązana $\mathrm{z}$ chęcią jej poddania przez imigranta31, przy jednoczesnym umożliwieniu imigrantom aktywnego udziału w społeczeństwie. Państwa skandynawskie mają możliwości, aby doprowadzić do udanego scalenia ludności napływowej. Większość imigrantów zdecydowała się na wyjazd ze względów ekonomicznych lub prześladowań. Dlatego obecnie chcą żyć w spokoju i rozwijać się. Sporą grupę stanowią także wschodni chrześcijanie, zaratusztrianie, bahaici i żydzi etc. uciekający przed radykalnym islamem. Te grupy mimo swojego konserwatyzmu, wydają się bardziej podatne na integrację. Rządy skandynawskie powinny w pierwszej kolejności zapewnić imigrantom odpowiednie warunki do życia. Koszty związane z polityką imigracyjną mogą doprowadzają do niezadowolenia społecznego. Jednak zaniedbanie integracji będzie jeszcze bardziej niebezpieczne. Trzeba przeciwstawiać się nietolerancji i radykalizacji rdzennej ludności, wymagając jednocześnie poszanowania praw przez imigrantów. Powstawanie etnicznych dzielnic, w których szerzy się przestępczość nie pozwala na odpowiednie warunki życia imigrantów. Pamiętajmy, że środowiska imigranckie nie są jednorodne, a często konflikty przenoszone są z kraju pochodzenia np. Izraelczycy z Palestyńczykami, Kurdowie z Turkami. System wartości ludności imigranckiej różni się od skandynawskiego co wywołuje problemy oraz nieporozumienia. Najniebezpieczniejsze jednak jest ryzyko otwartego konfliktu. Wpływ fundamentalistów na środowiska imigranckie może doprowadzić do eskalacji przemocy. Potrzebna jest spójna polityka imigracyjna która może umożliwić zgodne współżycie obu grup.

\section{Podsumowanie}

Państwa skandynawskie dostosowują swoją politykę do zmieniającej się sytuacji demograficznej swoich krajów. Skandynawia jest bardzo otwarta na imigrantów. Jednak widać rosnące poczucie niepewno-

\footnotetext{
${ }^{31}$ A. Grzymała-Kazłowska, „Integracja” - próba rekonstrukcji pojęcia, [w.] A. Dąbrowska-Korzus (red.), Problemy integracji imigrantów. Koncepcje, badania, polityki, Warszawa 2008, s. 35-36.
} 
ści, zwłaszcza wobec napływu cudzoziemców z poza europejskiego kręgu kulturowego. Dlatego w krajach tych wyraźnie zauważa się zaostrzenia w kwestii zdobycia zezwolenia na pobyt i pracę. Najbardziej widać ograniczenia w polityce imigracyjnej Danii, a najmniej Szwecji.

Kraje skandynawskie starają się zintegrować już przybyłych imigrantów, w tym zachęcić ich do aktywnego udział w życiu społecznym, kulturalnym i zawodowym. Jednak integracja generuje koszty pokrywane przez państwo, a docelowo ogół obywateli. Rozbudowywane są instytucje zajmujące się imigrantami, prowadzone są zajęcia językowe i nauka o społeczeństwie, wspomagane są zrzeszenia imigranckie i wspólnoty religijne. Fundusze przeznaczane na ten cel są znaczne, a wobec kryzysu ekonomicznego może nastąpić zniechęcenie Skandynawów do ponoszenia tych kosztów. Skandynawia jest natomiast atrakcyjna dla imigrantów, gdyż mogą się oni tam cieszyć wolnością słowa i przekonań, mają zagwarantowaną pomoc socjalną i większe bezpieczeństwo niż w rodzimych krajach objętych często konfliktami. Należy pamiętać, że imigranci to często prześladowani chrześcijanie, bahaici, zaratusztrianie, muzułmanie rożnych nurtów etc. Dlatego należałoby zwiększyć udział tych grup, bardziej skłonnych do integracji i dyskryminowanych we własnych krajach. Wobec cudzoziemców potrzebne są sprawne działania władz w ramach polityki mieszkaniowej, zatrudnienia, bezpieczeństwa, rozwoju kultury i wzajemnego zrozumienia. Imigracja jest zjawiskiem pożądanym wobec zmniejszającej się dzietności w Skandynawii. Rodzi jednak sporo zagrożeń, dlatego potrzebne jest zastanowienie się nad jej formą i skalą. Pozytywne wydaje się zwiększenie imigracji z Europy Wschodniej, z kręgu kultury latynoskiej o normach społecznych bliższych europejskim, a także azjatyckiej, gdzie wartości są mniej nastawione na konfrontacje z normami skandynawskimi. Ważne jest szerzenie tolerancji zarówno wśród społeczności rdzennej, jak i napływowej. Tylko wówczas obie grupy społeczne mogą wspólnie współżyć i doprowadzić do prawdziwej integracji w duchu pozytywnych wartości. Należy pamiętać, że „wyzwanie stwarza niepewność, ale jeszcze nie zagrożenie. 
Marcin Wysocki - Państwa skandynawskie wobec zagrożeń...

Jednak, jeśli podmioty bezpieczeństwa nie podejmują w odpowiednim czasie działań zmierzających do rozwiązania powstającego problemu, wyzwania mogą wygenerować zagrożenia"32. Warto wykorzystać doświadczenia skandynawskie przy tworzeniu polskiej polityki migracyjnej, a dzięki temu zmniejszyć możliwości wystąpienia lub skalę ewentualnych zagrożeń.

\section{Bibliografia:}

Banaś M., Wielość kultur, różnorodność tradycji, jedno społeczeństwo. Szwedzki model polityki integracyjnej, Instytut Studiów Regionalnych UJ, http://www.isr.wsmip.uj.edu.pl/documents/3337228/64d5af4d-167e4f49-bf92-120135d1a1df. [dostęp: 2-05-2018].

Country Reports on Human Rights Practices for 2017 - Denmark, Department of State: Bureau of Democracy, Human Rights and Labor, https://www.state.gov/j/drl/rls/hrrpt/humanrightsreport/index.htm?ye ar=2017\&dlid=277159. [dostęp: 2-05-2018].

Country Reports on Human Rights Practices for 2017 - Sweden, Department of State: Bureau of Democracy, Human Rights and Labor, https://www.state. gov/j/drl/rls/hrrpt/ humanrightsreport/index.htm?year=2017\&dlid=277159. [dostęp: 2-052018].

Esping-Andersen G., Trzy światy kapitalistycznego państwa dobrobytu, wyd. Difin, Warszawa 2010.

Grzela J., Równość płci jako fundament zrównoważonych społeczeństw nordyckich, wyd. PTSM, http://ptsm.edu.pl/wp-content/uploads/2016/01/ ptsm-4-tom-2-grzela.pdf. [dostęp: 2-05-2018].

Grzymała-Kazłowska A., „Integracja” - próba rekonstrukcji pojęcia, [w.] A. Dąbrowska-Korzus (red.), Problemy integracji imigrantów. Koncepcje, badania, polityki, wyd. UW, Waraszawa 2008.

Huntington S. P., Zderzenie cywilizacji, wyd. MUZA SA, Warszawa 2001.

32 R. Zięba, O tożsamości nauki o bezpieczeństwie, „Zeszyty Naukowe AON” 2012, nr 1 (86), s. 12. 
Iternational Religious Freedom Report 2017: Sweden, Department of State: Bureau of Democracy, Human Rights, and Labor, https://www.state.gov/j /drl/rls/irf/religiousfreedom/index.htm?year=2017\&dlid=280964 [dostęp: 2-05-2018].

International Religious Freedom Report 2017: Denmark, Department of State: Bureau of Democracy, Human Rights, and Labor, https://www.state.gov/j $/ \mathrm{drl} / \mathrm{rl}$ / $/$ irf/religiousfreedom/index.htm?year=2017\&dlid=280900 [dostęp: 2-05-2018].

International Religious Freedom Report 2017: Norway, Department of State: Bureau of Democracy, Human Rights, and Labor, https://www.state.gov/j /drl/rls/irf/religiousfreedom/index.htm?year=2017\&dlid=280944 [dostęp: 2-05-2018].

Kobierecka A., Kobierecki M., W poszukiwaniu źródeł międzynarodowej atrakcyjności Szwecji. Wymiar kulturowy, „Politeja” 2017 nr 3 (48), wyd. Księgarnia Akademicka, Kraków 2017.

Kowol A., Wariant szwedzki ekonomii dobrobytu. Teoria i praktyka, http://szwe cja.adamkowol.info/ [dostęp: 2-05-2018].

Kubitsky J., Alfabet szwedzki , wyd. Difin, Warszawa 2011.

Lieder W., Oświata w szwedzkim modelu państwa opiekuńczego, [w.] W. Anioł (red.), Analizy Norden Centrum, nr 1 (21), wyd. Fundacja Naukowa Norden Centrum, Warszawa 2014.

Lewandowska K., Tematyka imigracyjna w literaturze norweskiej od połowy lat 80-tych XX wieku, Wydział Neofilologii Uniwersytetu im. Adama Mickiewicza, Poznań 2010.

Olszewski R., Bezpieczeństwo współczesnego świata, wyd. Adam Marszałek, Toruń 2005.

Pawlik A., Słownik wiedzy ekonomicznej, wyd. Uniwersytet HumanistycznoPrzyrodniczy, Kielce 2010

Polityka migracyjna jako instrument promocji zatrudnienia i ograniczania bezrobocia, Ośrodek Badań nad Migracjami UW, Warszawa 2007, http://mighealth.net/pl/images/3/36/Promocja_zatrudnienia.pdf. [dostęp: 2-05-2018].

Pokruszyński W., Teoretyczne aspekty bezpieczeństwa, wyd. WSGE, Józefów 2010.

Scheffer P., Druga ojczyzna. Imigranci w społeczeństwie otwartym, wyd. Czarne, Wołowiec 2010. 
Marcin Wysocki - Państwa skandynawskie wobec zagrożeń...

Statystyka dotyczq̨a migracji i populacji migrantów, Eurostat Statistics Explained, http://ec.europa.eu/eurostat/statisticsexplained/index.php? title=Migration_and_migrant_population_statistics/pl.

Wiśniewski J., Mobilność pracowników i usług w regionie Morza Bałtyckiego, Biuletyn Analiz UKIE Nr 19, https://www.msz.gov.pl/resource/33fa04e3d22f-43b3-a348-fab07b8c28f1:JCR.

Zawadzki K., Szwecja i Dania, [w.] Z. Wiśniewski (red.), K. Zawadzki (red.), Aktywna polityka rynku pracy w Polsce $w$ kontekście europejskim, wyd. Pracownia Sztuk Plastycznych, Toruń 2010.

Zięba R., O tożsamości nauki o bezpieczeństwie, „Zeszyt Naukowy AON” 2012, nr 1 (86). 